\title{
Dilemmaenes århundre
}

«Dessuten bidro jeg til at familien unngikk en tragedie,» sa jordmoren til forfatteren Xinran i den dokumentariske boken Tapte døtre - fortellinger om savn og kjœrlighet (1, kap. 3). Hun har nettopp forklart at det var hennes oppgave å «fjerne» nyfødte pikebarn, ofte ved å ta livet av dem. I boken forteller fattige kinesiske mødre hvordan de er blitt frarøvet sine døtre, dels som konsekvens av Kinas ettbarnspolitikk, dels på grunn av tradisjoner og økonomiske realiteter.

Spedbarnsdrap er blitt utøvd til alle tider, med ulike begrunnelser, og blir fortsatt praktisert, skrev sjefredaktør Julian Savulescu i en lederartikkel i Journal of Medical Ethics for ett år siden (2). Den innledet et spesialnummer om abort og spedbarnsdrap - en respons på filosofene Alberto Giubilini \& Francesca Minervas kontroversielle artikkel After-birth abortion - why should the baby live? (3). De argumenter for at drap på nyfødte bør kunne godtas i alle situasjoner der abort anses som moralsk akseptabelt, også der barnet er friskt. De går altså mye lenger enn man gjør i Nederland, der eutanasi av syke nyfødte er tillatt etter den såkalte Groningenprotokollen (4).

Savulescu ble kraftig kritisert for å ha publisert Giubilini \& Minervas artikkel. Han forsvarte seg med at det var viktig med en seriøs diskusjon om drap av nyfødte og var opptatt av at den ble satt i sammenheng både med svangerskapsavbrudd og medisinsk praksis som tillater at behandling avsluttes eller ikke igangsettes: «practices that end life, which society already accepts, even if they are euphemistically redescribed» (2). Artiklene i mai 2013-utgaven av Journal of Medical Ethics er verdt å lese, vel å merke hvis man ikke blir plaget av å få egne oppfatninger utfordret.

For hva er et liv, og når er det akseptabelt å avslutte det? Som leger er vi nødt til å forholde oss til dette spørsmålet. Vi er alle bundet av legeetikken og imperativet primum non nocere (først og fremst ikke skade). Men hvordan? På et eller annet punkt, på linjen fra å nekte prevensjon via abort, spedbarnsdrap og aktiv dødshjelp til deltakelse i dødsstraff og drap, vil de aller fleste nå grensen for når de mener det er uakseptabelt å avslutte et liv. Hvor denne grensen går, vil variere - med samfunnsforhold, livsbetingelser og verdisyn. Og vi bør tåle at den varierer.

Vi må også tåle at det kan være vanskelig å være hundre prosent konsekvent. Hvis vi tar avstand fra eutanasi av syke nyfødte, hvorfor er det enklere å anbefale svangerskapsavbrudd hvis de samme sykdommene kan påvises ved tidlig ultralyd eller ved undersøkelse av befruktede egg? Svært mange av oss vil mene at det er en uhyrlig tanke å forfølge Giubilini \& Minervas resonnement om at det kan være akseptabelt å ta livet av friske nyfødte. Men hvorfor synes vi det er greit når det samme livet avsluttes på et tidligere tidspunkt fordi vi har ressurser og teknologi til å påvise graviditeten tidlig nok? Noen hevder at alt må gjøres for å berge et liv, men er det så enkelt? Det er også et spørsmål om hvem som skal reddes: Den du har foran deg eller de(n) som påvirkes av det du gjør med den du har foran deg? De fleste abortmotstandere vil redde en livstruende syk gravid kvinne selv om det innebærer at fosteret dør. Det er også et etisk dilemma dersom en lege velger å bruke alle ressurser på å redde ett liv, men velger å se bort fra køen av hjelptrengende som derigjennom fratas muligheter til behandling og omsorg - og liv.

Nye muligheter innen medisinsk diagnostikk og behandling gir oss flere dilemmaer å forholde oss til. Vi må ha en beredskap til å behandle disse når de oppstår. Det krever etisk bevisste leger, pasienter og politikere som har respekt for at dette er vanskelig og kan håndtere uenighet. Det betyr ikke at alt er akseptabelt. Men vi bør velge våre kriger med omhu.

I den pågående diskusjonen om reservasjonsrett er frontene blitt unødig skarpe. «Legen skal sette pasienten - ikke seg selv - i sentrum,» sier reservasjonsmotstanderne. Selvsagt. En god lege skal lytte til og respektere pasientens ønsker. Men det er ikke alltid det samme som å gjøre det pasienten ber om. Noen hevder at det er utidig hvis leger bringer egne oppfatninger inn i konsultasjonen. Men hvis pasientene kan få det de trenger fra en automat med retningslinjer og rettigheter, er det vel unødig dyrt å gå veien om legen?

I et annet kapittel i boken jeg nevnte innledningsvis, har Xinran funnet en kraftig nedkjølt nyfødt jente etterlatt på fortauet. Hun stormer med barnet til nærmeste sykehus, men blir stoppet i mottakelsen fordi ingen nyfødte kan tas imot med mindre moren har gyldig fødelisens. «Har du virkelig tenkt å stå og se på at dette barnet dør foran øynene dine?» roper Xinran. «Sykehuset er ansvarlig for å utføre sitt arbeid i tråd med myndighetenes ettbarnspolitikk. Sykehuspersonell har ikke rett til å se bort fra den politikken. Hvis vi gjør det, mister vi alle jobben,» forklarte legen.

\footnotetext{
Litteratur

1. Xinran X. Tapte døtre - fortellinger om savn og kjærlighet. Oslo: Gyldendal, 2010. 2. Savulescu J. Abortion, infanticide and allowing babies to die, 40 years on. J Med Ethics 2013; 39: 257-9.

3. Giubilini A, Minerva F. After-birth abortion: why should the baby live? J Med Ethics 2013; 39: 261-3

4. Verhagen E, Sauer PJ. The Groningen protocol - euthanasia in severely ill newborns. N Engl J Med 2005; 352: 959-62.
} 